\title{
Pemberian Magnesium Sulfat Intravena Meningkatkan Efek Analgesia Pascaoperasi pada Bedah Mayor Menggunakan Anestesi Umum
}

\author{
Hengki Irawan, I Made Subagiartha, I Made Gede Widnyana \\ Bagian Anestesi dan Terapi Intensif \\ Fakultas Kedokteran Universitas udayana/Rumah Sakit Umum Pusat Sanglah
}

\begin{abstract}
Abstrak
Penatalaksanaan nyeri akut pascaoperasi merupakan tugas penting dokter anestesi. Morfin banyak digunakan untuk mengontrol nyeri pascaoperasi. Tujuan penelitian ini untuk mengetahui pengaruh pemberian $\mathrm{MgSO}_{4}$ intravena selama operasi terhadap efek analgesia dan kebutuhan morfin pascaoperasi. Penelitian ini adalah uji klinik blok tersamar ganda. Tiga puluh enam subjek usia 21-55 tahun dialokasikan ke dalam kelompok A yang diberikan $\mathrm{MgSO}_{4} 30 \mathrm{mg} / \mathrm{kgBB}$ intravena 15 menit dilanjutkan $15 \mathrm{mg} / \mathrm{kgBB} / \mathrm{jam}$ sampai akhir operasi dan kelompok B diberikan $\mathrm{NaCl} 0,9 \%$ dengan volume sama yang menjalani operasi bedah mayor di RSUP Sanglah Denpasar pada Juni-Agustus 2014. Data hasil penelitian dianalisis dengan Uji Mann-Whitney. Nilai visual analog scale (VAS) diam dan bergerak pada jam ke-4 dan ke-8 pada kelompok Mg berbeda bermakna $(\mathrm{p}<0,05)$. Perbedaan konsumsi morfin pascaoperasi pada jam ke-4, ke-8, dan ke-24 berbeda bermakna $(\mathrm{p}<0,05)$. Simpulan penelitian ini adalah pemberian $\mathrm{MgSO}_{4}$ intravena selama operasi meningkatkan efek analgesia dan menurunkan kebutuhan morfin pascaoperasi.
\end{abstract}

Kata kunci: Analgesia pascaoperasi, anestesi umum, bedah mayor, magnesium sulfat

\section{Intravenous Magnesium Sulphate Administration to Improve Post- operative Analgesia Effect in Major Surgery with General Anesthesia}

\begin{abstract}
Relieving acute post-operative pain is an important role of anesthesiologist. Morphine is frequently used to control moderate to severe post operative pain. The objective of this study is to understand the effect of intravenous $\mathrm{MgSO}_{4}$ administration in improving post-operative analgesia effect. This study was a doubleblind randomized block clinical trial. The subjects of this study were patients who underwent major surgeries in Sanglah Hospital during the period of June to August 2014. Thirty six subjects age 21-55 years allocated to group A received intravenous $\mathrm{MgSO}_{4} 30 \mathrm{mg} / \mathrm{kgBW}$ intravenous bolus in 15 minutes followed by $15 \mathrm{mg} / \mathrm{kgBW} /$ hour until the surgery is finished and group B received $\mathrm{NaCl} 0.9 \%$ with the same volume. Data were then analyzed using the Mann-Whitney Test. The stationary and mobile VAS scores in the $4^{\text {th }}$ and $8^{\text {th }}$ hour in $\mathrm{Mg}$ group were significantly different $(\mathrm{p}<0.05)$. Post-operative morphine consumptions in the $4^{\text {th }}, 8^{\text {th }}$, and $24^{\text {th }}$ hour were significantly different between the $\mathrm{Mg}$ and $\mathrm{NaCl} 0.9 \%$ groups $(\mathrm{p}<0.05)$. It is concluded that the administration of intravenous $\mathrm{MgSO}_{4}$ during operation increases analgesia effect and reduces post-operative morphine need
\end{abstract}

Key words: General anesthesia, magnesium sulfate, major surgery, post-operative analgesia

Korespondensi: Hengki Irawan, dr., Bagian Anestesi dan Terapi Intensif Fakultas Kedokteran Universitas Udayana/ Rumah Sakit Umum Pusat Sanglah, Jl. Diponegoro No. 1 Denpasar 80114, Telp. (0361) 227911, Mobile 081320300048, Email irwan_hengki@yahoo.com 


\section{Pendahuluan}

Mengatasi nyeri akut pascaoperasi merupakan tanggung jawab penting bagi dokter anestesia. Morfin sering dipergunakan untuk mengontrol nyeri pascaoperasi pada nyeri sedang sampai berat. Pemberian morfin secara intravena (i.v.) memungkinkan penanganan nyeri yang cepat dan membatasi risiko overdosis. ${ }^{1}$

American Society of Anestesiologists (ASA) menyatakananalgesiamultimodaladalah kunci penanganan nyeri pascaoperasi. Penanganan nyeri yang baik akan meningkatkan hasil akhir pembedahan dengan mengurangi morbiditas dan mempercepat waktu pemulihan. Analgesia multimodal terbukti dapat menurunkan stres pascaoperasi, mengurangi nyeri pada pasien dengan komorbit yang berhubungan dengan pernapasan, jantung, komplikasi trombotik, mual, muntah, ileus, peningkatan katabolisme, disfungsi kognitif, memfasilitasi pemulihan dengan mempercepat saat pemberian nutrisi, mobilisasi, dan juga mengurangi lama tinggal di rumah sakit. ${ }^{2}$

Magnesium telah dilaporkan menghasilkan efekanalgesiayangbaikuntukpenatalaksanaan nyeri neuropatik, potensiasi morfin analgesia, dan juga mengurangi toleransi morfin. ${ }^{3}$ Sebagai agen antagonis reseptor $N$-methyl $D$-aspartat (NMDA) dalam sistem saraf pusat, magnesium menurunkan sensitisasi nosireseptor perifer dan respons stres pada pembedahan, sehingga dapat menurunkan kebutuhan opioid dalam periode perioperatif. Kebanyakan penelitian menunjukkan bahwa magnesium perioperatif dapat mengontrol respons kardiovaskular pada saat intubasi trakea, mengurangi kebutuhan anestesi, dan mempunyai opioid sparing effect dalam periode perioperatif. Namun, beberapa studi melaporkan efek tersebut terbatas atau tidak ada sama sekali. ${ }^{4}$

Magnesium sulfat $\left(\mathrm{MgSO}_{4}\right)$ sudah sering kali digunakan pada berbagai situasi klinis, seperti takiaritmia, miokardial dan neuronal iskemia, asma, spasmofilia, preeklamsi, tokolisis, serta kejadian menggigil pascaanestesi. Sejak 1990, pengaruh magnesium sulfat untuk mengurangi nyeri pascaoperasi dan berbagai sparing efect terhadap konsumsi opioid pascaoperasi telah diteliti di bagian ginekologi, oftalmik, dan juga operasi lutut artroskopi. ${ }^{5}$ Tujuan penelitian ini ialah mengetahui pengaruh pemberian $\mathrm{MgSO}_{4}$ terhadap efek analgesia dan kebutuhan morfin pascaoperasi.

\section{Subjek dan Metode}

Rancangan penelitian ini merupakan uji klinik dengan cara randomisasi blok tersamar ganda yang dilakukan prospektif terhadap 36 subjek untuk mengetahui nilai visual analogue scale (VAS) dan total konsumsi morfin dalam 24 jam setelah pemberian $\mathrm{MgSO}_{4}$ intravena selama operasi bedah mayor dengan anestesia umum di Rumah Sakit Umum Pusat Sanglah Denpasar periode Juni-Agustus 2014. Kriteria inklusi adalah usia 21-55 tahun, jenis operasi bedah mayor, serta status fisis ASA 1-2; dan kriteria eksklusi ialah mempunyai indeks massa tubuh (IMT) $<18,9 \mathrm{~kg} / \mathrm{m}^{2}$ atau $>24,9 \mathrm{~kg} / \mathrm{m}^{2}$, alergi terhadap $\mathrm{MgSO}_{4}$ dan antiinflamasi nonsteroid (AINS), riwayat mendapatkan obat analgetika secara kronik, riwayat gangguan fungsi ginjal dan hati, serta ketergantungan alkohol.

Subjek dipuasakan 8 jam praoperasi. Obat diberikan di ruang operasi dengan pengawasan oleh dokter residen anestesia. Setelah sampel berada di ruang persiapan kamar operasi, dilakukan pencatatan identitas, pemasangan kateter intravena ukuran G18, serta diberikan penjelasan mengenai mesin patient-controlled analgesia (PCA) yang dioperasikan sendiri oleh pasien dengan menekan tombol pada mesin PCA apabila merasa nyeri. Subjek dimasukkan ke dalam ruang operasi, kemudian dilakukan pemasangan alat monitor noninvasif (tekanan darah automatis, elektrokardiografi, dan pulse oksimetri.

Pasien kelompok A diberikan $\mathrm{MgSO}_{4} 20 \%$ $30 \mathrm{mg} / \mathrm{kgBB}$ bolus intravena dalam 15 menit, dilanjutkan dosis $15 \mathrm{mg} / \mathrm{kgBB} / \mathrm{jam}$, sedangkan pada kelompok B diberikan $\mathrm{NaCl}$ 0,9\% dengan volume yang sama. Induksi anestesia dimulai dengan terlebih dulu melakukan preoksigenasi memakai oksigen $100 \%$ selama tiga menit, dan diberikan fentanil $2 \mathrm{mcg} / \mathrm{kgBB}$. Selanjutnya, 
diberikan propofol memakai target controlled infusion (TCI) model Schnider dengan target konsentrasi $4 \mathrm{mcg} / \mathrm{mL}$, kemudian disuntikkan atrakurium 0,5 mg/kgBB intravena. Suplemen analgesia diberikan ketorolak 0,5 mg/kgBB intravena.

Ventilasi tekanan positif diberikan melalui sungkup muka dengan oksigen 100\% 12 kali per menit setelah tidak bernapas. Setelah onset fentanil tercapai dalam 5 menit dan pelumpuh otot tercapai dalam waktu 3 menit, dilakukan laringoskopi serta intubasi trakea pada menit ke-5. Kedalaman anestesia dipelihara dengan mempergunakan oksigen: $\mathrm{N}_{2} \mathrm{O}(1: 2)$, propofol TCI model Schnider dengan target konsentrasi efek $4 \mathrm{mcg} / \mathrm{mL}$. Fentanil tambahan $0,5 \mathrm{mcg} /$ kgBB diberikan secara intermiten, jika terdapat peningkatan tekanan darah sistol dan laju nadi lebih dari $20 \%$ dari tekanan darah sistol dan laju nadi sebelum pembedahan dimulai.

Pemeriksaan magnesium plasma dilakukan saat preoperasi dan pascaoperasi. Jika tekanan sistol $<90 \mathrm{mmHg}$ atau MAP menurun $>20 \%$ dari awal, berikan efedrin $5 \mathrm{mg}$ intravena. Jika nadi kurang dari 45 kali/menit diberikan atropin $0,5 \mathrm{mg}$ intravena. Jika terjadi keluhan pada pasien akibat pemberian $\mathrm{MgSO}_{4}$, seperti badan terasa panas, skotomata, mual, muntah, penglihatan kabur dan atau ganda, kelemahan otot, dan juga gangguan irama jantung sebagai komplikasi pemberian $\mathrm{MgSO}_{4}$, diberikan 1 gram kalsium glukonas intravena. Pada akhir pembedahan, dilakukan pencatatan durasi operasi dan anestesia serta jumlah kebutuhan $\mathrm{MgSO}_{4}$ yang diperlukan intraoperatif. Subjek diekstubasi setelah napas spontan adekuat dengan volume tidal $6-8 \mathrm{~mL} / \mathrm{kgBB}$ dan bila diperlukan dapat diberikan reverse.

Nilai VAS ditentukan dengan cara mengukur jarak dari sebelah kiri garis horizontal dengan panjang $100 \mathrm{~mm}$ yang sudah ditandai pasien pada saat jam ke-4, 8, dan 24 pascaoperasi.

Evaluasi VAS dilakukan saat skor Aldrette 10 , subjek akan diberikan morfin dosis titrasi 2 mg bolus intravena perlahan sebagai analgesia awal bila nilai VAS $\geq 30 \mathrm{~mm}$. Observasi selama 5 menit, dapat diulang kembali sampai VAS di bawah $30 \mathrm{~mm}$. Selanjutnya bila di ruangan VAS $\geq 30 \mathrm{~mm}$ subjek dipersilakan untuk memencet tombol pada mesin PCA dengan obat morfin intravena dan pengaturan PCA, yaitu demand dose $1 \mathrm{mg}$, locked out interval 6 menit, dosis maksimum dalam 4 jam sebesar $10 \mathrm{mg}$.

Total dosis morfin pascaoperasi pada jam ke-4, 8, dan juga 24 yang terekam dalam history mesin PCA dicabut. Ketorolak 0,5 mg/kgBB diberikan dengan interval waktu 8 jam, bila terjadi efek samping gatal yang mengganggu diberikan dipenhidramin $10 \mathrm{mg}$ i.v. Bila pasien mual atau muntah diberikan metokloperamid $10 \mathrm{mg}$ i.v. Bila terjadi efek samping yang serius akibat pemakaian morfin, seperti oversedasi dan depresi napas diberi terapi nalokson dosis titrasi sesuai protokol, lalu pasien dikeluarkan dari penelitian.

\section{Hasil}

Distribusi proporsi dan analisis uji chi-kuadrat dilakukan terhadap jenis kelamin serta status fisis ASA. Usia, berat badan, tinggi badan, serta indeks massa tubuh (IMT) ditampilkan dalam rata-rata dan standar deviasi dengan uji-t.

Karakteristik menurut usia, jenis kelamin, berat badan, tinggi badan, dan status fisis ASA antara kelompok $\mathrm{MgSO}_{4}$ dan kelompok $\mathrm{NaCl}$ $0,9 \%$ secara statistika tidak berbeda bermakna ( $>>0,05$; Tabel 1).

Sebelum melakukan perbandingan variabel, dilakukan uji normalitas pada masing-masing kelompok mempergunakan Uji Shapiro-Wilk. Berdasarkan pada hasil uji normalitas tersebut, didapatkan variabel yang berdistribusi normal pada kedua kelompok adalah usia serta berat badan. Selanjutnya, dilakukan uji rata-rata dengan mempergunakan uji parametrik pada variabel berdistribusi normal. Untuk variabel yang tidak berdistribusi normal maka uji ratarata dengan menggunakan uji nonparametrik, yaitu Uji Mann-Whitney (Tabel 2).

Berdasarkan pada hasil analisis didapatkan bahwa variabel nilai VAS diam 4 dan 8 jam, VAS bergerak 4 dan 8 jam, dan konsumsi morfin 4 , 8, dan 24 jam memiliki perbedaan bermakna secara statistika $(\mathrm{p}<0,05)$, sedangkan variabel VAS diam 24 jam dan juga VAS bergerak 24 jam tidak mempunyai perbedaan bermakna secara statistika ( $p>0,05$; Tabel 3). 
Tabel 1 Karakteristik Sampel berdasarkan Kelompok Perlakuan

\begin{tabular}{|c|c|c|c|}
\hline \multirow[b]{2}{*}{ Karakteristik } & \multicolumn{2}{|c|}{ Kelompok } & \multirow[b]{2}{*}{ Nilai $F_{1}$} \\
\hline & $\mathrm{MgSO}_{4}(\mathrm{n}=18)$ & $\begin{array}{c}\mathrm{NaCl} 0,9 \% \\
(n=18)\end{array}$ & \\
\hline Usia (tahun) & $37,2 \pm 9,4$ & $38,17 \pm 8,2$ & $0,764^{\mathrm{a}}$ \\
\hline \multicolumn{4}{|l|}{ Jenis kelamin } \\
\hline Laki-laki & 6 & 1 & $0,088^{\mathrm{b}}$ \\
\hline Perempuan & 12 & 17 & \\
\hline \multicolumn{4}{|l|}{ Status fisis } \\
\hline ASA 1 & 11 & 6 & $0,095^{c}$ \\
\hline ASA 2 & 7 & 12 & \\
\hline Berat badan (kg) & $54,5 \pm 10,73$ & $57,33 \pm 7,73$ & $0,370^{\mathrm{a}}$ \\
\hline Tinggi badan $(\mathrm{cm})$ & $158,22 \pm 7,72$ & $159,33 \pm 7,28$ & $0,628^{d}$ \\
\hline IMT $\left(\mathrm{kg} / \mathrm{m}^{2}\right)$ & $21,60 \pm 2,67$ & $22,56 \pm 2,36$ & $0,152^{\mathrm{d}}$ \\
\hline
\end{tabular}

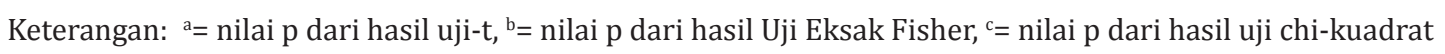
$\mathrm{d}=$ nilai $\mathrm{p}$ dari hasil Uji Mann-Whitney

Pada variabel penilaian VAS diam maupun bergerak pada jam ke-4 dan ke-8, didapatkan secara statistika berbeda bermakna $(\mathrm{p}<0,05)$, sedangkan nilai VAS diam dan bergerak antara kelompok $\mathrm{MgSO}_{4}$ dan kelompok $\mathrm{NaCl}$ 0,9\% pada jam ke-24 didapatkan secara statistika tidak berbeda bermakna ( $p>0,05)$. Nilai VAS diam dan bergerak pada jam ke-4, 8, serta 24 lebih rendah pada kelompok $\mathrm{MgSO}_{4}$. Terdapat kecenderungan nilai VAS diam dan bergerak yang menurun sampai dengan 24 jam pertama (Gambar 1).

Total konsumsi morfin pascaoperasi diukur dengan cara melihat rekaman data pada mesin

Tabel 2 Hasil Uji Normalitas antara Kedua Kelompok Perlakuan

\begin{tabular}{|c|c|c|}
\hline \multirow[b]{2}{*}{ Variabel } & \multicolumn{2}{|c|}{ Kelompok } \\
\hline & $\begin{array}{l}\mathrm{MgSO}_{4} \\
\text { Nilai p }\end{array}$ & $\begin{array}{c}\text { NaCl } 0,9 \% \\
\text { Nilai p } \\
\end{array}$ \\
\hline Usia & 0,405 & 0,137 \\
\hline Berat badan & 0,081 & 0,207 \\
\hline Tinggi badan & 0,635 & 0,037 \\
\hline IMT & 0,255 & 0,047 \\
\hline VAS diam 4 jam & $<0,001$ & 0,002 \\
\hline VAS diam 8 jam & $<0,001$ & 0,011 \\
\hline VAS diam 24 jam & $<0,001$ & 0,001 \\
\hline VAS bergerak 4 jam & $<0,001$ & 0,032 \\
\hline VAS bergerak 8 jam & $<0,001$ & 0,011 \\
\hline VAS bergerak 24 jam & $<0,001$ & $<0,001$ \\
\hline Konsumsi morfin 4 jam & $<0,001$ & 0,272 \\
\hline Konsumsi morfin 8 jam & $<0,001$ & 0,108 \\
\hline Konsumsi morfin 24 jam & 0,003 & 0,149 \\
\hline
\end{tabular}


Tabel 3 Nilai Statistik Variabel berdasarkan Kelompok Perlakuan

\begin{tabular}{|c|c|c|c|c|}
\hline \multirow{2}{*}{ Variabel } & \multicolumn{2}{|c|}{ Kelompok } & \multirow{2}{*}{$\begin{array}{c}\text { Beda } \\
\text { Rata-rata }\end{array}$} & \multirow{2}{*}{ Nilai $p$} \\
\hline & $\mathrm{MgSo}_{4}(\mathrm{n}=18)$ & NaCl 0,9\% (n=18) & & \\
\hline VAS diam 4 jam & $2,22 \pm 4,28$ & $7,39 \pm 6,78$ & 5,17 & 0,024 \\
\hline VAS diam 8 jam & $3,06 \pm 5,95$ & $10,22 \pm 8,37$ & 7,16 & 0,011 \\
\hline VAS diam 24 jam & $2,56 \pm 4,93$ & $7,0 \pm 5,9$ & 4,44 & 0,059 \\
\hline VAS bergerak 4 jam & $14,61 \pm 7,11$ & $28,5 \pm 9,23$ & 13,89 & $<0,001$ \\
\hline VAS bergerak 8 jam & $16,67 \pm 7,81$ & $26,72 \pm 7,62$ & 10,05 & 0,002 \\
\hline VAS bergerak 24 jam & $11,72 \pm 3,29$ & $14,44 \pm 4,5$ & 2,72 & 0,118 \\
\hline Konsumsi morfin 4 jam & $0,94 \pm 1,21$ & $2,33 \pm 1,37$ & 1,39 & 0,004 \\
\hline Konsumsi morfin 8 jam & $2,61 \pm 2,17$ & $5,61 \pm 3,72$ & 3 & 0,004 \\
\hline Konsumsi morfin 24 jam & $4,50 \pm 4,00$ & $9,78 \pm 6,86$ & 5,28 & 0,008 \\
\hline
\end{tabular}

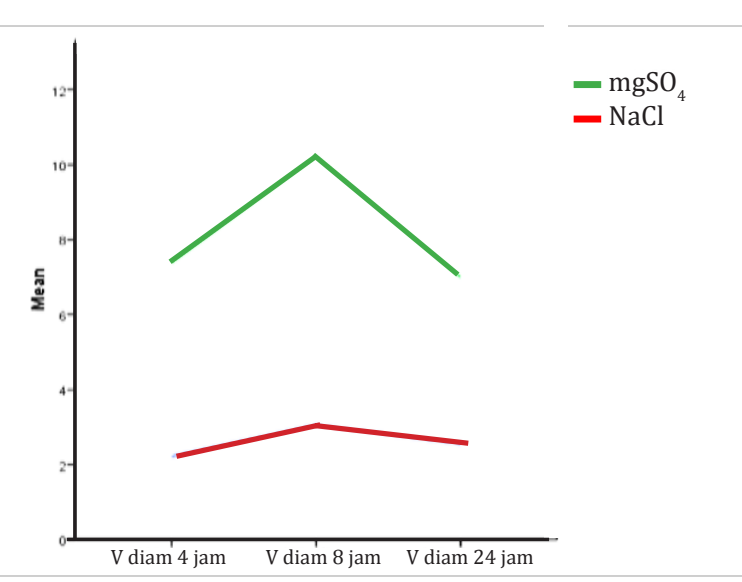

Gambar 1 Nilai VAS Diam Rata-rata berdasarkan Kelompok Perlakuan

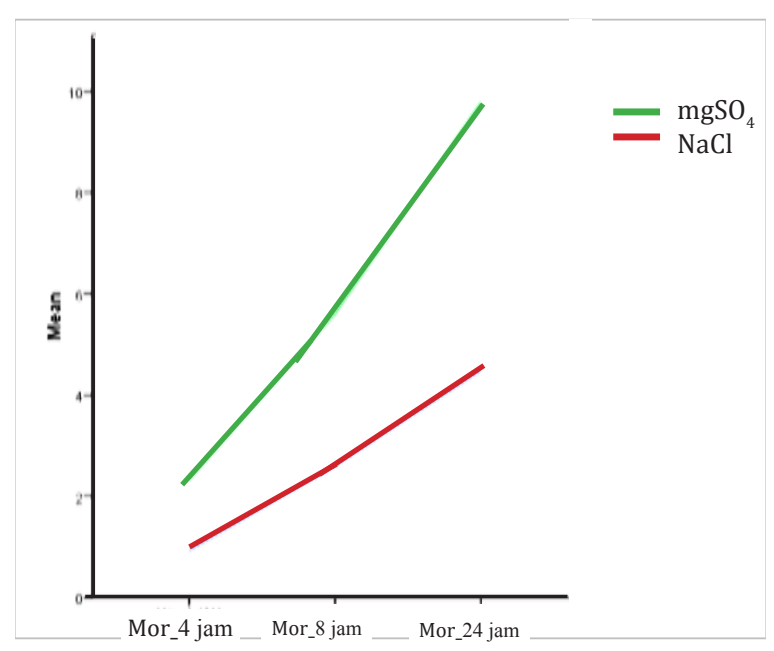

Gambar 3 Nilai Konsumsi Morfin pascaoperasi Rata-rata berdasarkan Kelompok Perlakuan

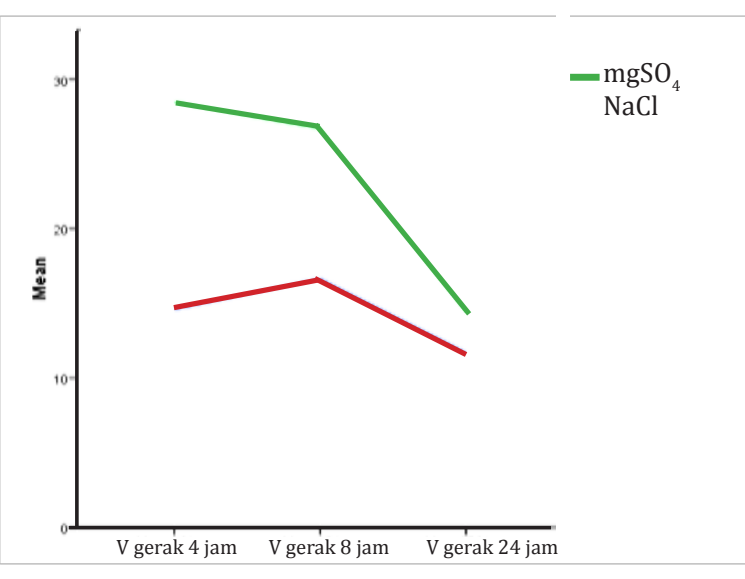

Gambar 2 Nilai VAS Bergerak Rata-rata berdasarkan Kelompok Perlakuan

PCA yang dinilai pada saat jam ke-4, 8, dan 24 pascaoperasi. Konsumsi morfin pascaoperasi pada saat jam ke-4, 8, dan 24 antara kelompok $\mathrm{MgSO}_{4}$ dan kelompok $\mathrm{NaCl} 0,9 \%$ berbeda bermakna menurut statistika ( $\mathrm{p}<0,05$; Tabel 3, Gambar 3).

\section{Pembahasan}

Teknik multimodal analgesia adalah strategi penatalaksanaan nyeri pascaoperasi memakai kombinasi analgetik opioid dengan non-opioid yang bekerja pada reseptor yang berbeda di sistem saraf pusat dan juga perifer. Penerapan konsep multimodal diharapkan meningkatkan kualitas analgesia sehingga nilai VAS dan juga konsumsi opioid dapat diturunkan. 
Pada hasil penelitian ini, pemberian $\mathrm{MgSO}_{4}$ intravena selama operasi dapat menghasilkan kualitas analgesia dengan nilai VAS yang lebih baik pascaoperasi pada jam ke-4 dan juga ke-8 $(p<0,05)$ sementara tidak lebih baik $(p>0,05)$ pada jam ke-24. Keadaan tersebut disebabkan pada jam ke-24, $\mathrm{MgSO}_{4}$ yang diberikan selama operasi mengalami penurunan kadar plasma sehingga efek analgesia berkurang.

Magnesium adalah inhibitor nonkompetitif terhadap inositol triphosphat-gated, saluran kalsium serta magnesium yang memiliki fungsi sebagai antagonis kalsium endogen dengan cara memengaruhi penyerapan dan distribusi. Magnesium juga menunjukkan efek modulasi pada saluran natrium dan juga kalium, sehingga akan memengaruhi potensiasi membran. Pada sistem saraf pusat, efek depresi timbul akibat pemberian magnesium yang bertindak sebagai antagonis pada reseptor $N$-methyl $D$-aspartat (NMDA) glutamat dan penghambat pelepasan katekolamin. ${ }^{6,8,9}$

Magnesium sulfat merupakan penghambat reseptor NMDA, sehingga mencegah sensitisasi sentral akibat stimulasi pada nosiseptif perifer. Magnesium juga memiliki efek antinosiseptif pada hewan serta manusia. Efek ini terutama didasarkan pada pengaruh magnesium sulfat terhadap pengaturan perpindahan kalsium ke dalam sel, yang secara fisiologis berperanan sebagai antagonis kalsium dan juga reseptor NMDA. Hubungan terbalik ditunjukkan antara derajat nyeri akibat proses pembedahan dan kadar magnesium serum. ${ }^{7,10,11}$

Konsumsi morfindalam 24jampascaoperasi pada kelompok $\mathrm{MgSO}_{4}$ lebih rendah sebesar 5,28 mg dibandingkan dengan kelompok $\mathrm{NaCl}$. Hasil penelitian ini sejalan dengan penelitian yang dilakukan Hwang dkk. ${ }^{10}$ serta penelitian Pastore dkk. ${ }^{12}$ menggunakan $\mathrm{MgSO}_{4} 50 \mathrm{mg} /$ $\mathrm{kgBB}$ bolus intravena yang dilanjutkan dengan $15 \mathrm{mg} / \mathrm{kgBB} / \mathrm{jam}$ pada operasi penggantian sendi panggul total mempergunakan anestesia spinal dapat menurunkan kebutuhan morfin pascaoperasi dengan skor nyeri lebih rendah. Penelitian yang dilakukan oleh Dabbagh dkk. ${ }^{5}$ pada pembedahan ortopedi ektremitas bawah menunjukkan hasil bahwa pemberian $\mathrm{MgSO}_{4}$ $8 \mathrm{mg} / \mathrm{kgBB}$ sampai akhir operasi memberikan gambaran skala nyeri serta kebutuhan morfin lebih rendah dibandingkan dengan kelompok kontrol.

\section{Simpulan}

Berdasarkan penelitian ini disimpulkan bahwa pemberian $\mathrm{MgSO}_{4} 30 \mathrm{mg}$ bolus dilanjutkan 15 $\mathrm{mg} / \mathrm{kgBB} / \mathrm{jam}$ pada pasien yang menjalani pembedahan mayor dengan anestesia umum memberikan kualitas analgesia lebih baik serta menurunkan pemakaian morfin pascabedah dalam 24 jam pertama.

\section{Daftar Pustaka}

1. Aubrun F, Mozoit JX, Riou B. Post operative intravenous morphine titrasion. $\mathrm{Br} \mathrm{J}$ Anaesth. 2012;108(2):193-201.

2. Bugada D, Matteo DM, Intelligente F, Cattaneo S, Romagnoli F, Minella C. A short on the current status of multimodal analgesia for post operative pain: how recent findings suggest a change in perspective. Intern J Anesthesiol Research. 2013;1:88-96.

3. Albrech E, Kirkham KR, Liu S, Brull R. Perioperative intravenous administration of magnesium sulphate and postoperative pain: a meta-analysis. Anesthesia. 2013;68: 79-90.

4. Piplai G, Mukhopadhyay M, Maji A, Barua D, Bhattacharya A, Mukhopadhyay A, dkk. Effect of magnesium sulpa he on hemodinamik response to endotracheal intubation, anaesthetic requirement and postoperative opioid consumption in patients undergoing spine surgery. Intern J Pharmacol Therapeutics. 2013;3:73-84.

5. Dabbagh A, Elyasi H, Razavi S, Fathi M, Rajaei S. Intravenous magnesium sulfate for post operative pain in patients undergoing lower limb orthopedic surgery. Acta Anaesthesiol Scand. 2009;53(8):1088-91.

6. Herroeder S, Schonherr ME, Hert SG, Holmann MW. Magnesium-essentials for anethesiologists. Anesthesiology. 2011; 114:971-93. 
7. Sirvinskas E, Laurinaitis R. Use of magnesium sulfate in anesthesiology. Medicina. 2002;38:695-8.

8. Murphy JD, Paskaradevan J, Eisler LL, Quanes JPP, Tomas VAG, Freck EA, dkk. Analgesic efficacy of continuous intravenous magnesium infusion as an adjuvant to morphine for postoperative analgesia: a systematic review and metaanalysis. Middle East J Anaesthesiol. 2013; 22:11-20.

9. Mentes O, Harlak T, Yigit T, Balkan A, Cosar A, Savaser A, dkk. Effect of intraoperative magnesium sulphate infusion on pain relief after laparoscopic cholecystectomy. Acta Anaesthesiol Scand. 2008;52:1353-9.

10. Hwang JY, Na HS, Jeon YT, Ra YJ, Kim CS,
Do SH. Infusion of magnesium sulphate during spinal anaesthesia improves post operative analgesia. $\mathrm{Br} \mathrm{J}$ Anaesthesia. 2009;104(1):89-93.

11. Lysakowski C, Dumon L, Czarnetzki C, Tramer MR. Magnesium as an adjuvant to postoperative analgesia: a systematic review of randomized trial. Intern Anesth Research Society. 2007;104:1532-9.

12. Pastore A, Lanna $M$, Lombardo $M$, Policastro C, Iacovazzo C. Intravenous infusion of magnesium sulphate during subarachnoid anaesthesia in hip surgery and its effect on post operative analgesia: our experience. Translational Med Unisa. 2013;5(6):18-21. 